\title{
Transactive DNA Binding Protein 43 Rather Than Other Misfolded Proteins in the Brain is Associated with Islet Amyloid Polypeptide in Pancreas in Aged Subjects with Diabetes Mellitus
}

\author{
Marina Leino $^{\mathrm{a}, \mathrm{b}}$, Svetlana N. Popova ${ }^{\mathrm{a}, \mathrm{b}}$ and Irina Alafuzoff ${ }^{\mathrm{a}, \mathrm{b}, *}$ \\ ${ }^{a}$ Department of Pathology, Uppsala University Hospital, Sweden \\ ${ }^{\mathrm{b}}$ Department of Immunology, Genetics and Pathology, Uppsala University, Sweden
}

Handling Associate Editor: Isidre Ferrer

Accepted 20 April 2017

\begin{abstract}
A link between diabetes mellitus (DM) related islet amyloid polypeptide (IAPP) and Alzheimer's disease (AD) related amyloid- $\beta(A \beta)$ has been suggested in epidemiological and clinical studies. In 2017, proof for existing interaction between type $2 \mathrm{DM}$ and $\mathrm{AD}$ on a molecular level was provided based on research carried out in experimental animal models. We assessed aging-related neurodegenerative lesions, i.e., misfolded proteins, associated with dementia such as hyperphosphorylated $\tau(\mathrm{HP} \tau), \mathrm{A} \beta, \alpha$-synuclein $(\alpha \mathrm{S})$, and phosphorylated transactive DNA binding protein 43 (pTDP43) seen in the brain and IAPP seen in the pancreas in subjects with and without DM applying immunohistochemical techniques. $\mathrm{HP} \tau$ in the brain and IAPP in the pancreas were observed in most subjects. The prevalence and the extent of all misfolded proteins increased with age but this increase was not influenced by DM. Interestingly the extent of misfolded proteins in the brain was higher in non-diabetics when compared with diabetics in demented. A significant correlation was observed between $\mathrm{HP} \tau, \mathrm{A} \beta, \alpha \mathrm{S}$, and pTDP43, whereas IAPP showed no association with $\mathrm{HP} \tau, \mathrm{A} \beta$, and $\alpha \mathrm{S}$. In subjects with DM, the extent of pTDP43 in brain correlated with the extent of IAPP in pancreas. Thus, there is no evidence of a link between AD-related pathology and DM in humans, whereas an association was found between pTDP43 and IAPP in DM. TDP43 is ubiquitously expressed in all organs but whether TDP43 is phosphorylated in other organs in DM or whether the phosphorylation of TDP43 is influenced by glucose metabolism is yet unknown.
\end{abstract}

Keywords: $\alpha$-synuclein, amyloid- $\beta$, diabetes mellitus, islet amyloid polypeptide, hyperphosphorylated $\tau$, phosphorylated transactive DNA binding protein 43

\section{INTRODUCTION}

With aging misfolded proteins, i.e., hyperphosphorylated $\tau(\mathrm{HP} \tau)$, amyloid- $\beta(\mathrm{A} \beta)$, phosphorylated

\footnotetext{
${ }^{*}$ Correspondence to: Prof. Irina Alafuzoff, MD, PhD, Department of Immunology, Genetics and Pathology, Uppsala University/Uppsala University Hospital, Dag Hammarskjölds väg 20, 75185 Uppsala, Sweden. Fax: +46 18 553354; E-mail: irina.alafuzoff@igp.uu.se.
}

$\alpha$-synuclein $(\alpha S)$, and phosphorylated transactive DNA-binding protein 43 (pTDP43) are frequently observed in the human brain tissue [1]. In excess, these proteins are associated with various age related neurodegenerative diseases. In Alzheimer's disease (AD), $\mathrm{HP} \tau$ and $\mathrm{A} \beta$ are deposited in the brain; in dementia with Lewy bodies, $\alpha \mathrm{S}$, and in frontotemporal lobar degeneration, pTDP43 is deposited in various cell compartments [2-5]. The deposition of 
these proteins is regionally predictable; thus, a reliable assessment of the extent of the pathologies can be carried out $[2,6,7]$. All these proteins can be seen simultaneously in one and the same subject, i.e., mixed pathologies $[8,9]$.

In diabetes mellitus (DM), deposition of misfolded protein, i.e., islet amyloid polypeptide (IAPP), is observed in the pancreas $[10,11]$. IAPP is secreted by the islet cells, and the deposition of IAPP is associated with type $2 \mathrm{DM}$ and in line with $\mathrm{AD}$, type 2 $\mathrm{DM}$ is more common in the aged [10,12]. To our knowledge, there are no reports with human subjects indicating that aging in itself would be associated with deposition of IAPP in the pancreas. Thus, in aging misfolded proteins can be seen in both brain and pancreas as soluble and as insoluble aggregates [13]. The insoluble aggregates have been referred to as "hallmark" lesions of a certain disease and they can readily be visualized as immunoreactivity (IR) as is seen in Fig. 1, in the postmortem tissue, brain and pancreas, applying immunohistochemical (IHC) techniques $[2,6,7,14]$.

Epidemiological studies have shown that there is an association between DM and dementia and thus $\mathrm{DM}$ has been suggested being a risk factor for $\mathrm{AD}$ [15-17]. It has been suggested that AD related and DM associated "pathologies" might influence each other and that a cross talk and/or cross-feeding might exist between the aggregation prone proteins [18].

In 2017, Moreno-Gonzales and colleagues reported that there is indeed a link between $A D$ and type $2 \mathrm{DM}$, i.e., misfolded IAPP produced in pancreas in type $2 \mathrm{DM}$ promoted $\mathrm{AD}$ pathology (A $\beta$ ) by cross-seeding [19]. This was observed both in cell culture and in transgenic animals. Based on the above a question arises as to whether the misfolded protein in the pancreas, i.e., IAPP might influence the protein aggregation in the brain, i.e., $\beta \mathrm{A}, \mathrm{HP} \tau, \alpha \mathrm{S}$, and $\mathrm{pTDP} 43$ and vice versa in humans.

Contrary to the above, neuropathological observations carried out on large human cohorts have not been able to show any link between AD and DM $[20,21]$. Moreover, recently in a clinical setting a lack of association was reported between biomarkers of neurodegeneration and type 2 DM [22].

The objective of this study was to investigate further the presumed association between the misfolded proteins in DM and neurodegeneration. We assessed the incidence and the extent of the insoluble aggregated proteins at the end stage, i.e., postmortem. We assessed pathologies such as $\operatorname{HP} \tau, \mathrm{A} \beta, \alpha \mathrm{S}$, and
pTDP43 observed in the brain tissue and the IAPP observed in the pancreas. The primary objective was to look for if any signs of association, i.e., cross talk and/or cross-seeding between these proteins could be detected. In addition, we looked for signs of colocalization of misfolded proteins in brain and pancreas.

\section{MATERIAL AND METHODS}

\section{Subjects}

During a six-year long period (from 2010 to 2015), an autopsy including a neuropathological investigation was carried out on 615 subjects, age ranging from 48 to 102 years, at Uppsala University Hospital (Fig. 2). The medical records revealed that 80 of the deceased subjects (13\%) had a clinical diagnosis of DM, age ranging from 48 to 95 years at death. In 74 (age range 48 to 87 years at death) of these 80 subjects, in addition to the brain tissue the pancreatic tissue was available for this study. An age and gender matched non-DM control group, including 74 subjects (49 to 87 years at death), was separated from the available cohort of 535 autopsy cases.

All procedures performed in the study involving human participants were in accordance with the ethical standards of the institutional and national research committee. The subjects included and/or their relatives had given their consent for the use of the tissue, and the study has been authorized by the regional Ethics Committee of Uppsala, Sweden \# 2011/286. The study was carried out in accordance with the 1964 Helsinki declaration and its amendment or comparable ethical standards.

\section{Sampling of the tissues}

At autopsy, the brains were weighed, fixed in excess of $4 \%$ buffered formaldehyde for a few days, and cut into 1-cm-thick coronal slices. Grossly notable lesions were noted as present or not on all fixed coronal slices. Following a standardized protocol, 16 brain specimens were sampled in each case, including areas such as the frontal, temporal, parietal, precentral, occipital cortices, the gyrus cinguli, and the striatum; basal forebrain including the amygdala, thalamus, and the anterior and posterior hippocampus; midbrain including the substantia nigra; pons including the locus coeruleus, medulla, vermis, and the cerebellar cortex. 

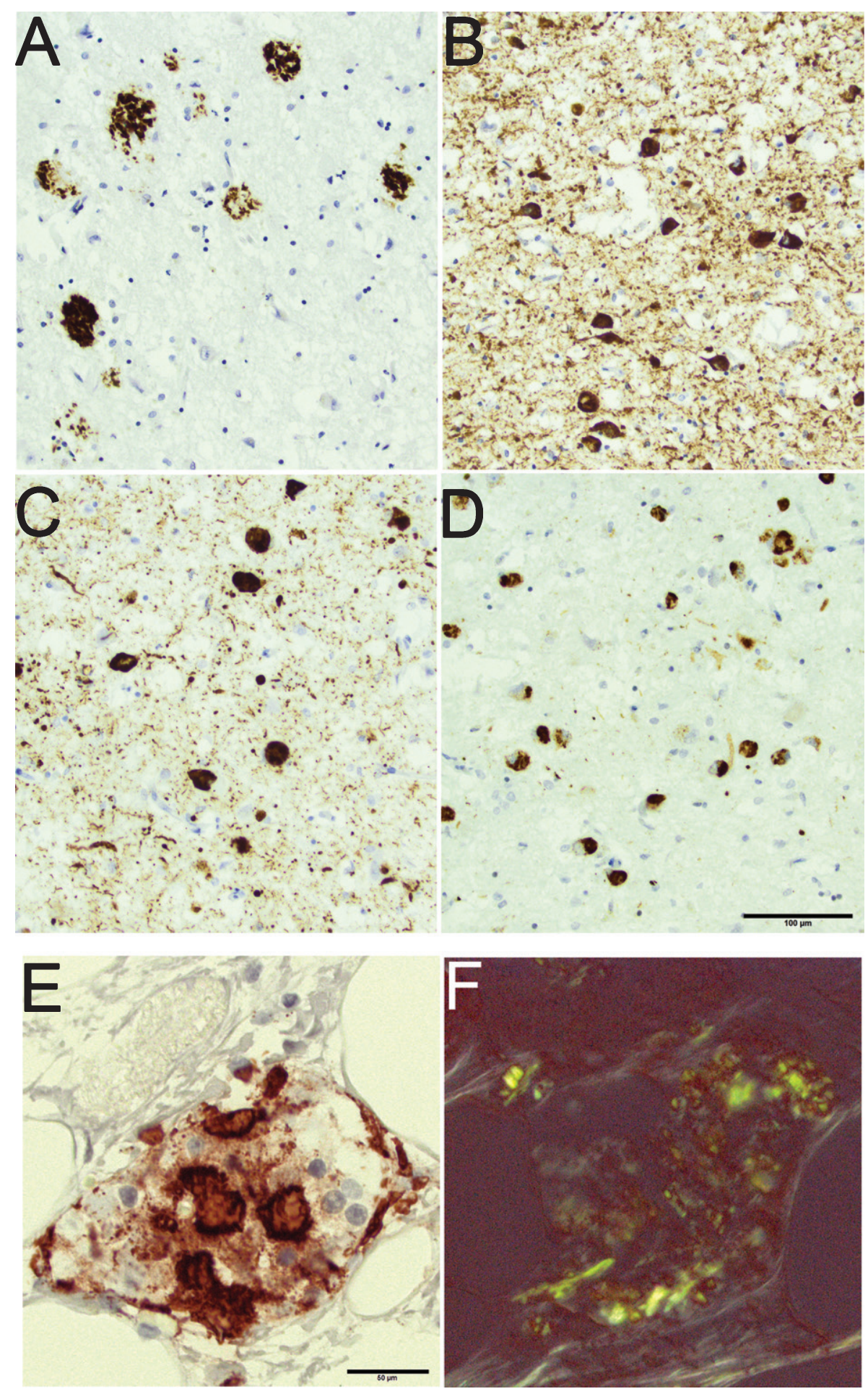

Fig. 1. An 80-year-old male with a clinical diagnosis of Alzheimer's disease with mixed pathology seen in the amygdala. Note the rounded amyloid- $\beta$ labeled aggregates in the brain parenchyma (A), the hyperphosphorylated- $\tau$ labeled neurites and intraneuronal tangles (B), the $\alpha$-synuclein labeled neurites and intraneuronal Lewy bodies (C), and the phosphorylated transactive DNA binding protein 43 labeled cytoplasmic inclusions (D). Pancreas tissue from an 85-year-old female with diabetes mellitus and signs of depression. Note the protein aggregates in an islet of Langerhans labeled with antibody directed to islet amyloid polypeptide (E). The same islet of Langerhans seen in Congo stain (F); note the birefringence of the protein. Scale bar: $100 \mu \mathrm{m}$ in A-D and $50 \mu \mathrm{m}$ in E,F. 


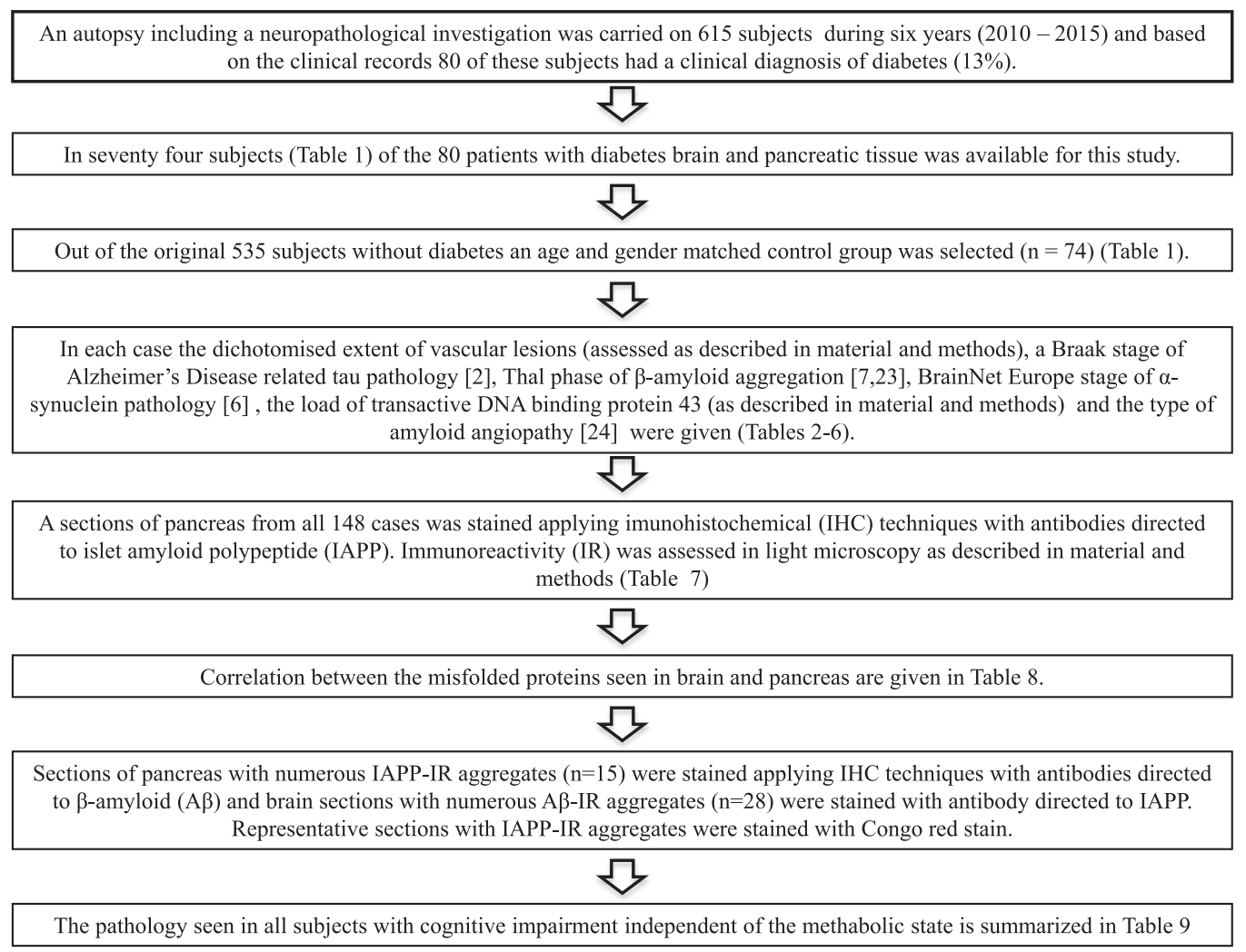

Fig. 2. Flowchart.

\section{Processing of tissue samples}

Seven $\mu \mathrm{m}$ thick sections of the paraffin embedded sampled brain tissue ( 16 blocks/case) was stained with hematoxylin-eosin (HE) stain to assess the microscopic lesions such as infarcts that were noted to be seen or not.

Pancreatic tissue was sampled at autopsy from the body of the organ and fixed in formalin for at least one week. Three $\mu \mathrm{m}$ thick sections of the paraffin embedded material were stained applying HE stain to assess the representability of the tissue.

\section{Immunohistochemistry}

For IHC stains carried out on the brain tissue, $7 \mu \mathrm{m}$ thick sections and on the pancreas $3 \mu \mathrm{m}$ thick sections were used. Briefly, HP $\tau / \mathrm{IR}$ was visualized using monoclonal antibody (mAb), clone AT8 (MN1020, ThermoScientific, Waltham, MA) in a dilution of 1:500 without pre-treatment; $A \beta / I R$ was visualized using mAb, clone 6F/3D (M0872, DakoCytomation, Glostrup, Denmark), in a dilution of 1:100 following pretreatment with $80 \%$ formic acid for $6 \mathrm{~h}$; phosphorylated $\alpha \mathrm{S} / \mathrm{IR}$ was visualized using mAb clone KM51 (NCL-L-ASYN, Leica Biosystems Newcastle Ltd, Newcastle upon Tyne, United Kingdom) in a dilution of 1:100 following heat pretreatment (autoclave) in a citrate buffer at $\mathrm{pH} 6.0$ and $80 \%$ formic acid for $5 \mathrm{~min}$; pTDP43/IR was visualized using mAb clone 11-9 (TIP-PTD-M01, Cosmo Bio Co. Ltd, Tokyo, Japan) in a dilution of 1:5000 following heat pretreatment (autoclave) in a citrate buffer at $\mathrm{pH}$ 6.0; and IAPP/IR was visualized with mAb, clone R10/99 (MA134685, ThermoScientific), in a dilution of 1:200 following heat pretreatment (autoclave) in a citrate buffer at $\mathrm{pH} 6.0$ and $80 \%$ formic acid for $5 \mathrm{~min}$. For detection of the antibody binding, the BrightVisonPlus detection system from Immunologic (Duiven, The Netherlands) with Romulin-3-amino-9-ethylcarbazol chromogen (BioCare Medical, Concord, CA) was used.

A representative section of the pancreas with notable IAPP/IR was stained with Congo-red stain to confirm the apple-green birefringence under polarized light (Fig. 1). 
Assessment of stained sections

All assessments were carried out in light microscopy, in magnifications $x 40-x 400$. The brain sections to be stained with the antibodies listed above were selected based on the requirements of the recommended staging protocols. For $\mathrm{HP} \tau$, the Braak stage (0, a,b, I-VI) [2]; for A $\beta$, the Thal phase (0-5) [7, 23]; and for $\alpha \mathrm{S}$, the Brain Net Europe stage (0-6) [6] were given. The type 1 or type 2 cerebral amyloid angiopathy was assigned as recommended by Thal and colleagues [24]. The pTDP43/IR was looked for and assessed in a dichotomized manner as seen or not seen in the section of the amygdala, medulla, and the hippocampus. All lesion types, i.e., intracytoplasmic inclusion and neurites were assessed. The semi-quantitative extent of pTDP43 was given as (0) not seen, (1) seen in one region, (2) seen in any two regions, and (3) seen in all three regions. The IAPP/IR was assessed by counting the IAPP/IR patches in ten randomly selected fields in magnification $\times 100$. A mean value of IAPP/IR was calculated for each case, i.e., sum of IR patches divided by the number of assessed fields.

The IAPP/IR was also sought after on a section obtained from the cortex. Cases that displayed a high load of $\mathrm{A} \beta(n=28)$ in the brain were chosen for this purpose. The $A \beta$ was also looked for on a section obtained from the pancreas. Cases that showed a high load of IAPP/IR $(n=15)$ were selected for this purpose.

\section{Statistical methods}

The IBM SPSS statistics software (IBM Corporation, Armonk, NY) was used. Statistical differences were analyzed using non-parametric Mann-Whitney U-test when two cohorts and Kruskall-Wallis test when more than 2 cohorts were compared, and the correlation was assessed by Spearman's correlation test.

\section{RESULTS}

\section{Demographics of the subjects}

The age at death of the selected study cohort, including 74 subjects with DM and 74 non-diabetics ranged from 48 to 87 years. Out of this cohort $16 \%$ had displayed cognitive impairment during life. The brain weight ranged from 988 to 1810 grams and the post mortem delay ranged from 10 to 336 hours. Demographics of the included subjects are given in Tables 1 and 2.

\section{Brain weight}

The brain weight decreased with age and differed significantly between the age groups $(p<0.05)$ in the whole cohort. This significant decrease was also noted for non-diabetics but lost in DM. A significant difference was noted between the youngest and middle aged subjects $(p<0.005)$ but only in non-diabetics (Table 2).

\section{The incidence of tissue alterations}

The incidence of protein alterations increased with age in the whole cohort of 148 subjects (Table 2). $\mathrm{HP} \tau /$ IR increased from 84 to $100 \%, \mathrm{~A} \beta / \mathrm{IR}$ from 16 to $54 \%, \alpha$ S/IR from 3 to $25 \%$, pTDP43/IR from 29 to $51 \%$, and IAPP/IR from 90 to $100 \%$. Only $3 \%$ of the

Table 1

Demographics of the included subjects

\begin{tabular}{lcccccc}
\hline Systemic disease & $\begin{array}{c}\text { Age } \\
\text { Groups }\end{array}$ & $\begin{array}{c}\text { Mean } \\
\text { Age } \pm \text { SE }\end{array}$ & Number & $\begin{array}{c}\text { Gender } \\
\text { F/M }\end{array}$ & $\begin{array}{c}\text { With cognitive } \\
\text { impairment }\end{array}$ & $\begin{array}{c}\text { PMD hours } \\
\text { mean } \pm \text { SE }\end{array}$ \\
\hline Non-diabetics & $\leq 65$ & $59.2 \pm 1.6$ & 16 & $8 / 8$ & 0 & $107 \pm 12$ \\
& $66-76$ & $71,6 \pm 0.6$ & 26 & $13 / 13$ & 3 & $100 \pm 11$ \\
& $\geq 77$ & $81.8 \pm 0.5$ & 32 & $13 / 19$ & 11 & $126 \pm 14$ \\
With diabetes & $49-87$ & $73.3 \pm 1.1$ & 74 & $34 / 40$ & 14 & $113 \pm 8$ \\
& $\leq 65$ & $58.6 \pm 1.6$ & 15 & $8 / 7$ & 1 & $133 \pm 16$ \\
& $66-76$ & $71.4 \pm 0.6$ & 28 & $14 / 14$ & 5 & $100 \pm 9$ \\
All subjects & $\geq 77$ & $81.9 \pm 0.5$ & 31 & $13 / 18$ & 4 & $102 \pm 10$ \\
& $48-87$ & $73.2 \pm 1.1$ & 74 & $35 / 39$ & 10 & $108 \pm 6$ \\
& $\leq 65$ & $58.9 \pm 1.1$ & 31 & $16 / 15$ & 1 & $120 \pm 10$ \\
& $66-76$ & $71.5 \pm 0.4$ & 54 & $27 / 27$ & 8 & $100 \pm 7$ \\
& $\geq 77$ & $81.8 \pm 0.3$ & 63 & $26 / 37$ & 15 & $114 \pm 8$ \\
& $48-87$ & $73.3 \pm 0.8$ & 148 & $69 / 79$ & 24 & $110 \pm 5$ \\
\hline
\end{tabular}

SE, standard error of means; F, female; M, male; PMD, postmortem delay. 
Table 2

Altered proteins and vascular alterations in the brain and islet amyloid polypeptide (IAPP) in the pancreas

\begin{tabular}{|c|c|c|c|c|c|c|c|c|c|c|c|}
\hline $\begin{array}{l}\text { Systemic } \\
\text { disease }\end{array}$ & $\begin{array}{l}\text { Age } \\
\text { groups }\end{array}$ & $n$ & $\begin{array}{l}\text { Brain weight } \\
\text { gram } \pm \text { SE }\end{array}$ & $\begin{array}{c}\mathrm{HP} \tau \\
n(\%)\end{array}$ & $\begin{array}{c}\mathrm{A} \beta \\
n(\%) \\
\end{array}$ & $\begin{array}{c}\text { CAA } \\
\text { Type1/2 } \\
\end{array}$ & $\begin{array}{c}\alpha S \\
n(\%)\end{array}$ & $\begin{array}{c}\text { TDP43 } \\
n(\%) \\
\end{array}$ & $\begin{array}{c}\text { micro/macro } \\
\text { infarcts }\end{array}$ & $\begin{array}{c}\text { IAPP IR } \\
n(\%)\end{array}$ & $\begin{array}{c}\mathrm{IAPP}_{\mathrm{IR}}^{\mathrm{a}} \\
\text { mean } \pm \mathrm{SE}\end{array}$ \\
\hline \multirow[t]{4}{*}{ Non-diabetics } & $\leq 65$ & 16 & $1472 \pm 39^{1,6}$ & $12(75)^{d}$ & $2(12)$ & $1 / 0$ & $1(6)$ & $5(31)$ & $2 / 3$ & $15(94)$ & $3.3 \pm 0.5$ \\
\hline & $\overline{66}-76$ & 26 & $1316 \pm 26^{1,6}$ & $26(100)$ & $12(46)$ & $1 / 4$ & $3(12)^{\mathrm{b}}$ & $13(50)$ & $2 / 6$ & $25(96)$ & $3.7 \pm 0.5$ \\
\hline & $\geq 77$ & 32 & $1382 \pm 25^{1}$ & $32(100)^{\mathrm{c}, \mathrm{e}}$ & $17(53)$ & $1 / 7$ & $9(28)$ & $19(59)$ & $1 / 10$ & $32(100)$ & $4.1 \pm 0.6$ \\
\hline & $49-87$ & 74 & $1378 \pm 18$ & $70(96)$ & $31(42)$ & $3 / 11$ & $13(18)$ & $37(50)$ & $5 / 19$ & $72(97)$ & $3.7 \pm 0.3$ \\
\hline \multirow[t]{4}{*}{ With diabetes } & $\leq 65$ & 15 & $1373 \pm 41$ & $14(93)$ & $3(20)$ & $0 / 1$ & $0(0)$ & $4(27)$ & $3 / 3$ & $13(87)$ & $2.6 \pm 0.8^{3,4,5}$ \\
\hline & $\overline{66}-76$ & 28 & $1358 \pm 36$ & $25(89)$ & $11(39)$ & $1 / 2$ & $8(29)$ & $9(32)$ & $3 / 11$ & $27(96)$ & $5.5 \pm 1.1^{3,4}$ \\
\hline & $\geq 77$ & 31 & $1326 \pm 29$ & $31(100)$ & $17(55)$ & $5 / 3$ & $7(23)$ & $13(42)$ & $6 / 10$ & $31(100)$ & $5.0 \pm 0.6^{3,5}$ \\
\hline & $48-87$ & 74 & $1348 \pm 20$ & $70(94)$ & $31(42)$ & $6 / 6$ & $15(20)$ & $26(35)$ & $12 / 24$ & $71(96)$ & $4.7 \pm 0.5$ \\
\hline \multirow[t]{4}{*}{ All subjects } & $\leq 65$ & 31 & $1424 \pm 29^{2}$ & $26(84)$ & $5(16)$ & $1 / 1$ & $1(3)$ & $9(29)$ & $5 / 6$ & $28(90)$ & $2.9 \pm 0.5$ \\
\hline & $6 \overline{6}-76$ & 54 & $1338 \pm 22^{2}$ & $51(94)$ & $23(43)$ & $2 / 6$ & $11(20)$ & $22(41)$ & $5 / 17$ & $52(96)$ & $4.6 \pm 0.6$ \\
\hline & $\geq 77$ & 63 & $1354 \pm 19^{2}$ & $63(100)$ & $34(54)$ & $6 / 10$ & $16(25)$ & $32(51)$ & $7 / 20$ & $63(100)$ & $4.5 \pm 0.4$ \\
\hline & $48-87$ & 148 & $1363 \pm 13$ & $140(95)$ & $62(42)$ & $9 / 17$ & 28 (19) & $63(43)$ & $17 / 43$ & $143(97)$ & $4.2 \pm 0.3$ \\
\hline
\end{tabular}

SE, standard error of means; $n$, number; $\mathrm{HP} \tau$, hyperphosphorylated tau; $\mathrm{A} \beta$, amyloid- $\beta ; \mathrm{CAA}$, cerebral amyloid angiopathy; $\alpha \mathrm{S}, \alpha$-synuclein; TDP43, transactive DNA binding protein 43, IR, immunoreactivity, ${ }^{\text {a }}$ number of IR patches of IAPP in ten randomly assessed fields in pancreas in magnification $\times 100 ;{ }^{b}$ a male subject, age 73 years at death with Multiple System Atrophy; ${ }^{c}$ a male subject, age 79 years at death with Progressive Supranuclear Palsy; ${ }^{\mathrm{d}}$ a 50 -year-old and ${ }^{\mathrm{e}}$ an 80 -year-old male with sparse HP $\tau$ pathology in hippocampus not sufficient for Braak staging[2]. Statistical differences, Kruskall-Wallis test ${ }^{1,2} p<0.05,{ }^{3} p<0.005$; Mann-Whitney U test ${ }^{4} p<0.05,{ }^{5} p<0.01,{ }^{6} p<0.005$.

subjects lacked any IAPP/IR in their pancreas, and a high extent of IAPP/IR was observed in $8 \%$ of the subjects. The incidence of protein alterations was not influenced by DM. The incidence of vascular lesions both micro- and macroscopic seemed to increase with age and infarcts were more common in subjects with DM, $49 \%$ versus $32 \%$ (Table 2 ).

\section{The extent of altered proteins in the brain and pancreas and DM}

The extent of $\operatorname{HP} \tau / \mathrm{IR}$ in the brain assessed applying the regional distribution of the misfolded protein increased with age. All of the youngest subjects $(\leq 65$ years) were in Braak stages 0-II, whereas most of the older subjects $(\geq 66)$ were in Braak stages II-IV (Table 3). DM did not influence the extent of HP $\tau$ /IR.

The extent of $A \beta / I R$ in the brain assessed applying the regional distribution of the misfolded protein increased with age. Most of the youngest subjects ( $\leq 65$ years) did not display any $A \beta / I R$ in the brain tissue, whereas phase 4-5 was primarily seen in the oldest subjects $(\geq 76)$. DM did not influence the extent of $A \beta / I R$ (Table 4).

The extent of $\alpha \mathrm{S} / \mathrm{IR}$ in the brain assessed applying the regional distribution of the misfolded protein increased with age. $\alpha \mathrm{S} / \mathrm{IR}$ was seen in $18 \%$ of the subjects, and most of these subjects were older than 65 years. In $8 \%$ of the whole cohort the highest stages of $\alpha \mathrm{S}$ pathology (BNE stage 5 and 6) was seen. DM did not influence the extent of $\alpha$ S/IR (Table 5).
Table 3

Percent of subjects with a given extent of hyperphosphorylated $\tau$ pathology (in three subjects * with hyperphosphorylated $\tau$ pathology, Braak staging could not be carried out)

\begin{tabular}{llccccr}
\hline Age group & & Number & \multicolumn{5}{c}{ Braak stage [2] } \\
\cline { 3 - 7 } & & & $0, \mathrm{a}, \mathrm{b}$ & I-II & III-IV & V-VI \\
\hline$\leq 65$ years & all & $30^{*}$ & 57 & 43 & & \\
& non-diabetic & $15^{*}$ & 80 & 20 & & \\
& diabetic & 15 & 33 & 67 & & \\
66-76 years & all & 54 & 37 & 41 & 13 & 9 \\
& non-diabetic & 26 & 23 & 46 & 23 & 8 \\
& diabetic & 28 & 50 & 35 & 4 & 11 \\
$\geq 77$ years & all & $61^{*}$ & 16 & 49 & 22 & 13 \\
& non-diabetic & $30^{*}$ & 13 & 50 & 17 & 20 \\
All & diabetic & 31 & 19 & 48 & 26 & 7 \\
& all & $145^{*}$ & 32 & 45 & 14 & 9 \\
& non-diabetic & $71^{*}$ & 31 & 42 & 16 & 11 \\
& diabetic & 74 & 34 & 47 & 12 & 7 \\
\hline
\end{tabular}

Table 4

Percent of subjects with a given extent of amyloid- $\beta$ pathology

\begin{tabular}{|c|c|c|c|c|c|c|c|}
\hline \multirow[t]{2}{*}{ Age group } & & \multirow[t]{2}{*}{ Number } & \multicolumn{5}{|c|}{$\begin{array}{c}\text { Thal phase } \\
{[7,23]}\end{array}$} \\
\hline & & & 0 & 1 & 3 & 4 & 5 \\
\hline \multirow[t]{3}{*}{$\leq 65$ years } & all & 31 & 87 & 13 & & & \\
\hline & non-diabetic & 16 & 94 & 6 & & & \\
\hline & diabetic & 15 & 80 & 20 & & & \\
\hline \multirow[t]{3}{*}{$66-76$ years } & all & 54 & 61 & 22 & 4 & 7 & 6 \\
\hline & non-diabetic & 26 & 54 & 23 & 4 & 8 & 12 \\
\hline & diabetic & 28 & 68 & 21 & 4 & 7 & \\
\hline \multirow[t]{3}{*}{$\geq 77$ years } & all & 63 & 46 & 29 & 6 & 13 & 6 \\
\hline & non-diabetic & 32 & 47 & 22 & 9 & 16 & 6 \\
\hline & diabetic & 31 & 45 & 36 & 3 & 10 & 6 \\
\hline \multirow[t]{3}{*}{ All } & all & 148 & 60 & 23 & 4 & 8 & 5 \\
\hline & non-diabetic & 74 & 59 & 20 & 5 & 9 & 7 \\
\hline & diabetic & 74 & 61 & 26 & 3 & 7 & 3 \\
\hline
\end{tabular}


The extent of pTDP43/IR in the brain while assessing three commonly affected regions (amygdala, hippocampus, and medulla) increased with age. In $43 \%$ of the whole cohort pTDP43/IR was observed. In the youngest age group, $29 \%$ of subjects were affected with pTDP43 pathology and in $8 \%$ of the whole cohort all three assessed regions were affected. DM did not influence the extent of pTDP43/IR (Table 6).

The extent of IAPP/IR in pancreas while applying a semiquantitative assessment strategy increased with age when all subjects were included (Table 2). The increase was close to significant $(p=0.07)$ for the whole cohort but significant when comparing the youngest subjects with oldest $(p<0.05)$. When only diabetics were included the increase in the extent of IAPP/IR with age was significant $(p=0.021)$ and when the youngest group was compared with the middle-aged or the oldest group ( $p<0.05$ and $p<0.01$ respectively). The mean extent of IAPP/IR did not

Table 5

Percent of subjects with a given extent of $\alpha$ synuclein pathology; One subject * with Multiple System Atrophy

\begin{tabular}{|c|c|c|c|c|c|c|c|c|}
\hline \multirow[t]{2}{*}{ Age group } & & \multirow[t]{2}{*}{ Number } & \multicolumn{6}{|c|}{ BNE stage [6] } \\
\hline & & & 0 & 1 & 3 & 4 & 5 & 6 \\
\hline \multirow[t]{3}{*}{$\leq 65$ years } & all & 31 & 97 & 3 & & & & \\
\hline & non-diabetic & 16 & 94 & 6 & & & & \\
\hline & diabetic & 15 & 100 & & & & & \\
\hline \multirow[t]{3}{*}{ 66-76 year: } & & $53^{*}$ & 81 & 5 & 4 & 2 & 4 & \\
\hline & non-diabetic & 26 & 88 & 4 & & & 4 & \\
\hline & diabetic & $27^{*}$ & 74 & 7 & 7 & 4 & 4 & \\
\hline \multirow[t]{3}{*}{$\geq 77$ years } & all & 63 & 76 & 3 & 5 & 5 & 8 & \\
\hline & non-diabetic & 32 & 72 & 3 & 3 & 6 & 13 & \\
\hline & diabetic & 31 & 81 & 3 & 7 & 3 & 3 & \\
\hline \multirow[t]{3}{*}{ All } & all & 148 & 82 & 4 & 3 & 3 & 5 & 3 \\
\hline & non-diabetic & 74 & 82 & 4 & 1 & 3 & 7 & 3 \\
\hline & diabetic & $73 *$ & 82 & 4 & 5 & 3 & 3 & 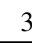 \\
\hline
\end{tabular}

differ significantly between DM and non-diabetic. In $57 \%$ of the subjects, the mean number of IAPP/IR patches was 4 or less and in $8 \%$ the mean number was more than 10 (Table 7). Fifteen percent of the subjects with DM had a high extent of IAPP/IR in their pancreas (IAPP/IR >10.1) when compared with $1 \%$ of the non-diabetic subjects. This difference was noted also for different age groups, i.e., 0 versus $7 \%$, 0 versus $25 \%$, and 3 versus $10 \%$ respectively.

\section{Correlation between altered proteins, the age of the subject and diabetes}

Overall the highest correlations were observed between misfolded proteins seen in the brain (Table 8). High and significant correlation was observed in the 148 subjects between the age of the subjects and $\mathrm{HP} \tau / \mathrm{IR}$, age and $\mathrm{A} \beta / \mathrm{IR}, \mathrm{HP} \tau$ and $\mathrm{A} \beta / \mathrm{IR}, \mathrm{HP} \tau$ and $\mathrm{pTDP} 43 / \mathrm{IR}, \mathrm{A} \beta$ and $\mathrm{pTDP} 43 / \mathrm{IR}$ and $A \beta$ and $\alpha S / I R$. This association was preserved in the 74 non-diabetic subjects, whereas it decreased or was lost, i.e., was insignificant in subjects with DM. Extent of IAPP/IR showed weak but significant correlation with age in the 148 assessed subjects. This significant correlation was also observed for the subjects with DM. A negative correlation $(r=-0.3$, $p<0.05$ ) was observed between IAPP/IR and A $\beta /$ IR in cognitively unimpaired subjects without DM. A significant correlation was detected between IAPP/IR and pTDP43/IR in subjects with DM $(r=0.2$, $p<0.05$ ) and when only the 12 subjects with DM and that displayed extensive IAPP/IR $(>9)$ were included the significance became higher $(r=0.8, p<0.005)$. A significant correlation was also observed in cognitively unimpaired subjects with DM $(r=0.3$, $p<0.05)$. This significant correlation was lacking

Table 6

Percent of subjects with a given extent of transactive DNA-binding protein 43 (TDP43)

\begin{tabular}{|c|c|c|c|c|c|c|}
\hline \multirow[t]{2}{*}{ Age group } & & \multirow[t]{2}{*}{ Number } & \multicolumn{4}{|c|}{$\begin{array}{l}\text { TDP43 seen in } 0,1 \text {, any } 2 \text {, all } 3 \text { regions } \\
\text { (medulla, amygdala, hippocampus) }\end{array}$} \\
\hline & & & 0 & 1 & 2 & 3 \\
\hline \multirow[t]{3}{*}{$\leq 65$ years } & all & 31 & 71 & 26 & & 3 \\
\hline & non-diabetic & 16 & 69 & 31 & & \\
\hline & diabetic & 15 & 73 & 20 & 7 & \\
\hline \multirow[t]{3}{*}{$66-76$ years } & all & 54 & 59 & 28 & 7 & 6 \\
\hline & non-diabetic & 26 & 50 & 34 & 12 & 4 \\
\hline & diabetic & 28 & 68 & 21 & 4 & 7 \\
\hline \multirow[t]{3}{*}{$\geq 77$ years } & all & 63 & 49 & 21 & 17 & 13 \\
\hline & non-diabetic & 32 & 41 & 19 & 18 & 22 \\
\hline & diabetic & 31 & 58 & 23 & 16 & 3 \\
\hline \multirow[t]{3}{*}{ All } & all & 148 & 57 & 25 & 10 & 8 \\
\hline & non-diabetic & 74 & 50 & 27 & 12 & 11 \\
\hline & diabetic & 74 & 65 & 22 & 8 & 5 \\
\hline
\end{tabular}


Table 7

Percent of subjects with a given extent of amylin/islet amyloid polypeptide (IAPP)

\begin{tabular}{|c|c|c|c|c|c|c|c|c|}
\hline \multirow[t]{2}{*}{ Age group } & & \multirow[t]{2}{*}{ Number } & \multicolumn{6}{|c|}{ IAPP immunoreactivity in the pancreas } \\
\hline & & & 0 & $\leq 2.0$ & $2.1-4.0$ & $4.1-6.0$ & $6.1-10.0$ & $>10.1$ \\
\hline \multirow[t]{3}{*}{$\leq 65$ years } & all & 31 & 10 & 35 & 26 & 13 & 13 & 3 \\
\hline & non-diabetic & 16 & 6 & 31 & 25 & 19 & 19 & \\
\hline & diabetic & 15 & 13 & 40 & 26 & 7 & 7 & 7 \\
\hline \multirow{3}{*}{ 66-76 years } & all & 54 & 4 & 30 & 26 & 15 & 12 & 13 \\
\hline & non-diabetic & 26 & 4 & 31 & 23 & 23 & 19 & \\
\hline & diabetic & 28 & 4 & 28 & 29 & 7 & 7 & 25 \\
\hline \multirow[t]{3}{*}{$\geq 77$ years } & all & 63 & & 29 & 25 & 19 & 21 & 6 \\
\hline & non-diabetic & 32 & & 38 & 25 & 12 & 22 & 3 \\
\hline & diabetic & 31 & & 19 & 26 & 26 & 19 & 10 \\
\hline \multirow[t]{3}{*}{ All } & all & 148 & 3 & 31 & 26 & 16 & 16 & 8 \\
\hline & non-diabetic & 74 & 3 & 34 & 25 & 17 & 20 & 1 \\
\hline & diabetic & 74 & 4 & 27 & 27 & 15 & 12 & 15 \\
\hline
\end{tabular}

Table 8

Correlation between the extent of "proteinopathy" seen in the brain $(\mathrm{HP} \tau, \mathrm{A} \beta, \alpha \mathrm{S}$ and $\mathrm{pTDP} 43)$ and in the pancreas (IAPP)

\begin{tabular}{|c|c|c|c|c|c|c|c|c|c|c|c|c|c|c|c|}
\hline & \multicolumn{15}{|c|}{ Spearman correlation coefficient $r$} \\
\hline & \multirow[b]{2}{*}{$n$} & \multicolumn{5}{|c|}{ age/ } & \multicolumn{3}{|c|}{$\mathbf{H P} \tau /$} & \multicolumn{2}{|c|}{$\mathbf{A} \boldsymbol{\beta} /$} & \multirow{2}{*}{$\frac{\text { pTDP43/ }}{\alpha S}$} & \multicolumn{3}{|c|}{ IAPP/ } \\
\hline & & $\overline{\mathrm{HP} \tau}$ & $\mathrm{A} \beta$ & pTDP43 & $\alpha S$ & IAPP & $\mathrm{A} \beta$ & pTDP43 & $\overline{\alpha S}$ & pTDP43 & $\alpha \mathrm{S}$ & & $\overline{\mathrm{HP} \tau}$ & $\mathrm{A} \beta$ & pTDP43 $\alpha \mathrm{S}$ \\
\hline All subjects & 148 & $0.4^{3}$ & $0.3^{3}$ & $0.2^{2}$ & $0.2^{1}$ & $0.2^{1}$ & $0.5^{3}$ & $0.4^{3}$ & $0.2^{2}$ & $0.3^{3}$ & $0.3^{3}$ & $0.2^{1}$ & & & \\
\hline nonDM & 74 & $0.5^{3}$ & $0.3^{2}$ & $0.4^{2}$ & $0.2^{2}$ & & $0.7^{3}$ & $0.5^{3}$ & $0.4^{2}$ & $0.5^{3}$ & $0.4^{2}$ & $0.3^{1}$ & & & \\
\hline DM & 74 & $0.3^{1}$ & $0.3^{2}$ & & & $0.3^{1}$ & $0.4^{2}$ & $0.3^{2}$ & & & & & & & $0.2^{1}$ \\
\hline nonCI & 124 & $0.4^{3}$ & $0.3^{2}$ & $0.2^{1}$ & $0.2^{2}$ & & $0.3^{3}$ & $0.3^{2}$ & & $0.2^{1}$ & $0.2^{1}$ & & & & \\
\hline CI & 24 & & & & & & $0.8^{3}$ & & & & & & & & \\
\hline nonDM/nonCI & 60 & $0.5^{3}$ & & & $0.3^{1}$ & & $0.5^{3}$ & $0.3^{1}$ & $0.4^{2}$ & $0.3^{1}$ & $0.4^{2}$ & $0.3^{2}$ & & $-0.3^{2}$ & \\
\hline nonDM/CI & 14 & & & & & & $0.9^{3}$ & & & & & & & & $-0.6^{1}$ \\
\hline $\mathrm{DM} /$ nonCI & 64 & $0.3^{1}$ & $0.3^{1}$ & & & & & $0.3^{1}$ & & & & & & & $0.3^{1}$ \\
\hline $\mathrm{DM} / \mathrm{CI}$ & 10 & & & & & & $0.9^{2}$ & & & & & & & & \\
\hline
\end{tabular}

$\mathrm{HP} \tau$, hyperphosphorylated tau (extent Braak stage [2]); A $\beta$, amyloid- $\beta$ (extent Thal phase [7, 23]); pTDP43, phosphorylated transactive DNA binding protein (extent: immunoreactivity to be seen in one, two or three regions, i.e., regions medulla, amygdala, hippocampus); $\alpha \mathrm{S}$, $\alpha$ synuclein (extent BNE stage [6]) IAPP, islet amyloid polypeptide (extent: the mean number of immunoreactive patches in ten randomly selected fields); DM, subjects with diabetes; nonDM, subjects without diabetes; CI, subjects with cognitive impairment; nonCI, subjects without cognitive impairment. Spearman correlation test ${ }^{1} p<0.05,{ }^{2} p<0.01,{ }^{3} p<0.0001, r$ values when $p<0.0001$ are given in bold.

in demented subjects with DM and was negative $(r=-0.6, p<0.05)$ in demented subjects without DM.

\section{Dementia and diabetes}

There were 24 subjects that had displayed cognitive impairment during life, 10 of them were subjects with DM (Table 9, cases 15 to 24). The most common cause of death was cardiovascular complication followed by bronchopneumonia, and DM did not influence the cause of death. The mean age at death (not significant) and the brain weight $(p<0.05)$ were lower in the group of cognitively impaired with DM when compared to the non-diabetics, and the mean extent of IAPP/IR (not significant) was higher in subjects with DM when compared with the non-diabetic group. The extent of all pathologies (HP $\tau, A \beta, \alpha S, p T D P 43)$ was higher (not significant) in subjects without diabetes. In both the DM and in the non-diabetic group some subjects displayed sparse and some extensive IAPP/IR. There were no significant differences in the definite diagnosis of neurodegeneration between subjects with or without DM (Table 9).

\section{Colocalization of $A \beta$ and IAPP}

IAPP/IR was not observed in the 28 sections of the frontal cortex with a high load of $A \beta / I R$, and $A \beta / I R$ was not observed in the 15 pancreas sections with a high load of IAPP/IR.

\section{DISCUSSION}

Here we found that the incidence and the extent of age related misfolded proteins seen in the brain or the pancreas increased with age. Noteworthy, this increase was not influenced by DM. Thirteen percent 
Table 9

Proteinopathy seen in the brain and pancreas in 24 subjects with cognitive impairment; case 1 to 14 without clinical diagnosis of diabetes, case 15 to 24 subjects with clinical diagnosis of diabetes

\begin{tabular}{|c|c|c|c|c|c|c|c|c|c|c|c|c|}
\hline & $\begin{array}{c}\text { IAPP }^{a} \\
\text { mean } \pm \text { SE }\end{array}$ & Age & $\begin{array}{c}\text { Sex } \\
\text { M/F }\end{array}$ & $\begin{array}{c}\mathrm{BW} \\
\text { grams }\end{array}$ & $\begin{array}{c}\text { Braak } \\
\text { HP } \tau \\
\text { stage [2] }\end{array}$ & $\begin{array}{c}\text { Thal } A \beta \\
\text { phase } \\
{[7,23]}\end{array}$ & $\begin{array}{c}\text { CAA } \\
\text { type [24] }\end{array}$ & $\begin{array}{l}\text { BNE } \alpha S \\
\text { stage [6] }\end{array}$ & $\mathrm{pTDP} 43^{\mathrm{b}}$ & $\begin{array}{c}\text { Vascular } \\
\text { pathology }\end{array}$ & PAD & $\begin{array}{c}\text { NIA-AA } \\
{[52,53]}\end{array}$ \\
\hline 1 & 1.2 & 72 & $\mathrm{M}$ & 1390 & 5 & 5 & 2 & 0 & 3 & 0 & $\mathrm{AD} / \mathrm{TDP}$ & High \\
\hline 2 & 8.7 & 75 & $\mathrm{~F}$ & 1275 & 5 & 5 & 1 & 0 & 3 & 1 & $\mathrm{AD} / \mathrm{TDP}$ & High \\
\hline 3 & 3.4 & 75 & M & 1495 & 3 & 1 & 2 & 6 & 3 & 0 & DLBD/TDP & intermediate \\
\hline 4 & 15.2 & 79 & M & 1515 & 0 & 0 & 0 & 0 & 0 & 0 & PSP & \\
\hline 5 & 5.1 & 79 & M & 1600 & 5 & 5 & 2 & 5 & 2 & 1 & AD/LBD/TDP & High \\
\hline 6 & 2.3 & 80 & $\mathrm{~F}$ & 1380 & 4 & 1 & 0 & 0 & 2 & 1 & AD/TDP & intermediate \\
\hline 7 & 6.6 & 80 & M & 1413 & 5 & 4 & 0 & 6 & 0 & 0 & $\mathrm{AD} / \mathrm{LBD}$ & High \\
\hline 8 & 5.3 & 81 & M & 1215 & 5 & 4 & 2 & 0 & 2 & 0 & $\mathrm{AD} / \mathrm{TDP}$ & High \\
\hline 9 & 1.6 & 82 & M & 1370 & 2 & 0 & 0 & 0 & 3 & 0 & FTLD/TDP & \\
\hline 10 & 1.5 & 83 & $\mathrm{~F}$ & 1580 & 5 & 4 & 2 & 0 & 3 & 0 & $\mathrm{AD} / \mathrm{TDP}$ & High \\
\hline 11 & 9.0 & 84 & M & 1493 & 5 & 3 & 0 & 4 & 3 & 0 & AD/LBD/TDP & High \\
\hline 12 & 6.9 & 85 & $\mathrm{~F}$ & 1310 & 1 & 0 & 2 & 0 & 0 & 0 & HS & \\
\hline 13 & 5.0 & 87 & $\mathrm{~F}$ & 1160 & 5 & 5 & 2 & 0 & 3 & 0 & AD/TDP & High \\
\hline 14 & 5.1 & 87 & M & 1215 & 2 & 1 & 0 & 0 & 3 & 0 & FTLD/TDP & \\
\hline$n=14$ & $5.5 \pm 1.0$ & $80.6 \pm 1.2$ & $9 / 5$ & $1387 \pm 37^{1}$ & $5.0 \pm 0.4$ & $2.7 \pm 0.6$ & & $1.5 \pm 0.7$ & $2.0 \pm 0.3$ & & & \\
\hline$\overline{15}$ & 4.2 & 62 & $\mathrm{~F}$ & 1235 & 1 & 0 & 0 & 0 & 3 & 0 & FTLD/TDP & \\
\hline 16 & 1.5 & 69 & $\mathrm{~F}$ & 1230 & 5 & 3 & 0 & 3 & 2 & 0 & AD/LBD/TDP & High \\
\hline 17 & 3.7 & 69 & $\mathrm{~F}$ & 1300 & 5 & 4 & 2 & 6 & 3 & 0 & $\mathrm{AD} / \mathrm{LBD} / \mathrm{TDP}$ & High \\
\hline 18 & 1.2 & 73 & M & 1475 & 0 & 1 & 2 & 0 & 0 & 0 & MSA & \\
\hline 19 & 24.1 & 73 & M & 1300 & 6 & 4 & 0 & 0 & 1 & 0 & $\mathrm{AD} / \mathrm{TDP}$ & High \\
\hline 20 & 0.9 & 75 & M & 1365 & 3 & 0 & 0 & 0 & 0 & 1 & $\mathrm{AgD}$ & \\
\hline 21 & 10.4 & 81 & $\mathrm{~F}$ & 1310 & 4 & 4 & 1 & 3 & 0 & 0 & $\mathrm{AD} / \mathrm{LBD}$ & intermediate \\
\hline 22 & 5.3 & 83 & $\mathrm{~F}$ & 1060 & 3 & 3 & 0 & 0 & 0 & 1 & $\mathrm{AD}$ & intermediate \\
\hline 23 & 7.3 & 84 & $\mathrm{~F}$ & 988 & 5 & 5 & 2 & 0 & 2 & 0 & $\mathrm{AD} / \mathrm{TDP}$ & High \\
\hline 24 & 8.0 & 84 & M & 1290 & 2 & 0 & 0 & 0 & 0 & 0 & FTLD/FUS & Low \\
\hline$n=10$ & $6.7 \pm 2.2$ & $75.3 \pm 2.4$ & $4 / 6$ & $1255 \pm 45^{1}$ & $4.3 \pm 0.7$ & $2.1 \pm 0.7$ & & $1.3 \pm 0.7$ & $1.1 \pm 0.4$ & & & \\
\hline$\overline{n=24}$ & $6.0 \pm 1.1$ & $78.4 \pm 1.3$ & $13 / 11$ & $1332 \pm 31$ & $4.7 \pm 0.4$ & $2.5 \pm 0.4$ & & $1.4 \pm 0.5$ & $1.6 \pm 0.3$ & & & \\
\hline
\end{tabular}

IAPP, islet amyloid polypeptide; ${ }^{a}$ mean number of IAPP immunoreactive patches in ten randomly selected fields assessed in magnification x 100: n, number; M, male; F, female; BW, brain weight; $\mathrm{HP} \tau$, hyperphosphorylated tau; $\mathrm{A} \beta, \beta$ amyloid; CAA, cerebral amyloid angiopathy; $\alpha \mathrm{S}, \alpha$ synuclein; pTDP43, phosphorylated transactive DNA binding protein; ${ }^{b}$ pTDP43 immunoreactivity to be seen in 1,2 , or 3 regions (medulla, amygdala, hippocampus); ${ }^{\mathrm{c}}$ macro- and/or microscopic lesions observed in hematoxylin-eosin stain in any of the assessed section; PAD, PathoAnatomical Diagnosis; AD, Alzheimer's disease; AgD, Argyrophilic grain Disease; DLBD, Diffuse Lewy body dementia; FTLD, Frontotemporal Lobar degeneration, FUS, fused in sarcoma; HS, hippocampal sclerosis; LBD, Lewy body disease; MSA, Multi System atrophy; NIA-AA, National Institute on Aging-Alzheimer's Association; Significant difference, non-parametric Mann-Whitney-U test ${ }^{1}$ $p<0.05$.

of our autopsy cohort of 615 subjects, age ranging from 48 to 102 years had DM, based on the medical records. In $93 \%$ of subjects with DM, tissue was available for this study. The percentage of $13 \%$ diabetics is well in line with the reported incidence of 10 to $20 \%$ of DM observed in Europeans over 65 years of age [25].

\section{IAPP immunoreactivity in pancreas in aged}

Numerous reports have indicated that aggregation of IAPP in the pancreatic tissue is a phenomenon related to DM [10, 11]. In 1990, it was reported that altered IAPP aggregates were seen in the pancreas in up to $77 \%$ of DM when compared to $7 \%$ in non-diabetic subjects [26]. In this study, we assessed the IAPP/IR in the endocrine part of the pancreas (the islets of Langerhans) applying IHC techniques. In many of the cases, the tissue was altered due to the postmortem delay, but the IHC technique readily visualized the IAPP/IR. The youngest subject (48 years old) had DM and already displayed IAPP/IR in pancreas, whereas lack of IAPP/IR was registered in only five subjects, age ranging from 50 to 71 years. Thus, contrary to the report by Clark and colleagues, we observed that almost all our subjects (97\%), independent of clinical diagnosis of DM, displayed IAPP/IR in their pancreas. The discrepant result when comparing our results with Clark and colleagues might be related to selection bias, methods used and to the population studied (Scandinavians versus Pima Indians). Contrary to our expectations, 
three of the subjects with DM lacked IAPP/IR and this might be due to selection bias; only one section obtained from the body of pancreas was investigated. Surprisingly, almost all aged non-diabetics in our study displayed IAPP/IR and this might be explained by the recent observations that a large number of adults in the U.S. have undiagnosed type $2 \mathrm{DM}$, and 5 to $10 \%$ of the European population display impaired glucose regulation $[27,28]$.

Not previously reported to our knowledge, we observed that the extent of IAPP/IR increased with age, and this increase was noted for the whole cohort of 148 subjects and for the 74 subjects with DM. Thus the increase of extent of IAPP/IR in the pancreas is an age- and DM-related phenomenon, i.e., IAPP/IR was significantly higher in the oldest group when compared to the youngest. This observation is in line with the previous reports indicating that the prevalence of impaired glucose regulation seems to increase with age [28]. The mean number of labeled islets of Langerhans in the pancreas did not differ significantly between the subjects with DM and nondiabetics, but a high extent of IAPP/IR was observed more often in subjects with DM. The reports indicating that there is a substantial number of undiagnosed subjects with type $2 \mathrm{DM}$ or with impaired glucose regulation is intriguing [27, 28]. The question arises as to whether the pathology seen by us postmortem is a sign of a prodromal stage of DM.

\section{Misfolded proteins in the brain}

The prevalence of aggregation prone proteins in the brain, i.e., $\mathrm{HP} \tau, \mathrm{A} \beta, \alpha-\mathrm{S}$, and pTDP43, increased with age. The most common alteration to be observed was $\operatorname{HP} \tau$ followed by A $\beta$, pTDP43, and $\alpha \mathrm{S}$. Thus, our results here are in agreement with previous reports [1]. This prevalence did not seem to be significantly influenced by DM. It was not only the prevalence but also the extent of $\operatorname{HP} \tau, A \beta, \alpha-S$, and pTDP43 that increased with age. The Braak stage of $\operatorname{HP} \tau$, the Thal phase of $A \beta$, and the BNE stage of $\alpha S$ increased with age for the whole study population. When assessed separately for DM and non-diabetics, no major differences in the patterns of the age-related changes were seen. These results are in line with previous reports [20]. A similar trend was also observed for pTDP43 pathology as assessed here, i.e., number of brain regions affected. Thus, our results imply that DM does not influence the prevalence or the extent of altered proteins to be seen in the aging brain.
In addition to altered proteins, the prevalence of vascular lesions increased with age in both DM and non-diabetic subjects, and vascular lesions were found to be more frequent in DM. This observation is in line with previous reports indicating that an association exists between the extent of vascular lesions and DM [29].

\section{Correlation between the misfolded proteins}

Extent of all assessed misfolded proteins was significantly influenced by the age. A significant correlation was also observed between $\operatorname{HP} \tau, A \beta$, pTDP43, and $\alpha \mathrm{S}$. Thus an association between AD related misfolded proteins and pTDP43 and $\alpha \mathrm{S} / \mathrm{IR}$ was observed. This might suggest that the AD related aggregation prone proteins might act as a seed to initiate aggregation of other proteins and thus this hypothesis should not be overlooked [18]. Contrary to the above, no correlation was observed between $\mathrm{HP} \tau, \mathrm{A} \beta$, and $\alpha \mathrm{S} / \mathrm{IR}$ in the brain and IAPP/IR in the pancreas. The extent of IAPP/IR did not show any association with AD-related pathology; moreover, a negative correlation was observed between IAPP and $A \beta / I R$ in cognitively unimpaired non-diabetics. Therefore, our results obtained in humans at the end stage, i.e., postmortem, do not support the epidemiological, clinical, or experimental data suggesting that a causative relationship exists between DM and $\mathrm{AD}$, i.e., misfolded protein IAPP acts as a seed for misfolding of $\mathrm{A} \beta, \mathrm{HP} \tau$, and $\alpha \mathrm{S}$ or vice versa [19]. Interestingly the extent of pTDP43/IR seen in as many as $43 \%$ of our cohort was significantly associated with IAPP/IR in subjects with DM. Noteworthy, when only 12 subjects with both DM and extensive IAPP/IR were included the correlation was strong $(r=0.8)$ and significant $(p<0.005)$. This correlation was also noted in the 64 cognitively unimpaired subjects with DM but was lacking in the 10 demented with DM. Surprisingly, a significant negative correlation between pTDP43 and IAPP/IR was observed for the 14 non-diabetic demented subjects (Table 8). Therefore, based on our finding, pTDP43/IR seems to be associated with IAPP/IR and DM. Recently it was reported that there is an interaction between IAPP and a single nucleotide polymorphism (SNP) on chromosome 12p12 (rs73069071) and this SNP has been shown to be associated with hippocampal sclerosis (HS) [30, 31]. Parallel with this, an association between HS and pTDP43 has been proposed by many $[32,33]$. Furthermore, in TDP43 transgenic mice impaired insulin mediated glucose uptake has 
been described [34]. Thus, there is indeed evidence for interplay between IAPP and TDP43. TDP43 is ubiquitously expressed in all organs, binds to both DNA and RNA and has multiple functions including transcriptional repression, pre-mRNA splicing and translational regulation $[35,36]$. Whether phosphorylation of TDP43 is influenced by impaired glucose metabolism has not yet been studied and whether phosphorylation of TDP43 can be observed in peripheral organs in diabetes has not been looked for. It is reported that up to $50 \%$ of $\mathrm{AD}$ patient display concomitant pTDP43 pathology and whether subjects with AD and concomitant pTDP43 suffer from DM has not been looked for [37].

\section{Colocalization of $A \beta$ and IAPP}

Already in 2010, it was reported that AD-related pathology was seen in pancreas in diabetics [38]. Following in 2013, it was reported that IAPP/IR was observed in the brains of demented subjects with type 2 DM [39]. We carried out the IHC stain on those cases that displayed an excess of the primary pathology (A $\beta$ or IAPP) and applied $\mathrm{mAb}$ while staining for IAPP and $A \beta$. We were unable to repeat any of the reported observations given above. There was no $\mathrm{A} \beta / \mathrm{IR}$ seen in the pancreas in 15 subjects with excess of IAPP/IR. Twelve of these subjects had DM, and 3 of these subjects had displayed cognitive impairment. There was no IAPP/IR seen in the 28 brain samples with excess of $A \beta / I R$. Twelve of these subjects had DM and 13 were demented. The differing results are probably due to the methodology, both tissue and methodology related. Recently in 2017, cross-seeding and colocalization of IAPP and A $\beta$ was reported to be seen in transgenic mice [19]. This finding was further highlighted by Ridler [40]. One factor that should be considered in the described experimental setting by Moreno-Gonzales and colleagues is the physiological increase of amyloid- $\beta$ protein precursor $(\mathrm{A} \beta \mathrm{PP})$ production seen in posttraumatic brains [41]. Thus, the inoculation of pancreatic aggregates into the brain (a trauma) as was carried out by Moreno-Gonzales and colleagues might cause a physiological increase in A $\beta P P$ production that in a setting of A $\mathrm{APP}$ transgenic mice might lead to $A \beta$ aggregation.

\section{Dementia and diabetes}

The overall incidence of dementia in developed countries has been reported as decreasing during the last few years, from $11.6 \%$ to $8.8 \%$ [42]. This decrease is considered as being attributed to social, behavioral, and medical factors. Out of our 148 subjects, $16 \%$ of the subjects displayed cognitive impairment. This incidence is somewhat higher than overall incidence probably due to a selection bias, i.e., reason to refer for autopsy varies. The distribution of dementia in our study cohort with or without DM was fairly even (10 and 14 subjects, respectively). There was no notable difference in the distribution of the definite diagnosis of dementia. One obstacle, however, is the lack of consensus criteria regarding vascular lesions to be assessed as being causative for dementia thus the vascular pathology might have been overlooked [43].

A link between cognitive impairment, i.e., dementia and DM has been suggested in epidemiological and clinical studies and in particular, it has been proposed that there is an association between DM and AD [17, 44, 45]. This presumption has been challenged by others suggesting that dementia in DM is primarily related to vascular alterations $[20,29$, 46-48]. Here, based on our results, assessing the hallmark lesions of $\mathrm{AD}$ and other dementias and the alteration related to DM, i.e., IAPP/IR, no association could be seen between DM and AD. The lack of a link between $\mathrm{AD}$ and $\mathrm{DM}$ is also supported by the observations that less AD related pathology has been reported to be seen in subjects with DM when compared to non-diabetic subjects [21, 49, 50]. Our results are in line with the above, as our demented subjects with DM displayed less misfolded proteins (not significant) in their brain when compared with nondiabetics. Further, in 2015, Moran and colleagues reported that no association could be found between $\mathrm{DM}$ and $\mathrm{A} \beta$ in the brain when assessed with ${ }^{11} \mathrm{C}$ Pittsburgh compound $B$ or with cerebrospinal fluid $A \beta_{42}$ levels [22]. In line with the above, Kuo and colleagues reported in 2015 that the hazard ratio for dementia in DM was associated with comorbidities such as hypertension, hyperlipidemia, coronary artery, and/or kidney disease-all risk factors for vascular lesions in the brain [51]. In line with the above vascular alterations were seen in $49 \%$ of subjects with DM when compared with $32 \%$ in non-diabetics in our cohort.

\section{Strength and weaknesses of the study}

The strength of this study is that we have assessed the pathological alterations in the brain and in the pancreas that have been reported as being associated with clinical conditions such as DM and dementia. 
The selection of cases was based on a known clinical condition, i.e., DM, the prevalence being in line with what is seen in the general population. An age and gender matched control group was selected from the original autopsy cohort. The prevalence of dementia was quite evenly distributed in non-DM and DM. We were able to assess objectively both the incidence and the extent of neurodegenerative alterations as well as the DM related aggregation of IAPP seen in the pancreas. One of the major weaknesses of the study is the assessment of vascular lesions limited to infarcts and cerebral amyloid angiopathy and the lack of consensus of vascular pathology to be assessed in the postmortem brain of demented. Thus, the vascular pathology might have been overlooked.

\section{Conclusion}

We found that the incidence and the extent of $\mathrm{HP} \tau, \mathrm{A} \beta, \mathrm{pTDP} 43, \alpha \mathrm{S}$, and IAPP increased with age, independent of DM. The definite diagnosis of dementia varied in both the DM and the non-diabetic cohort. We noted that two of the misfolded proteins were observed in virtually all of the subjects, i.e., $\mathrm{HP} \tau$ in the brain and IAPP in the pancreas. The high incidence of $\mathrm{HP} \tau$ pathology in the brains of the aged is well known, whereas the observation of IAPP in the pancreas in almost all of the subjects, even those not clinically diagnosed with DM, is intriguing. This might be related to a high number of aged displaying impaired glucose regulation and/or undiagnosed type $2 \mathrm{DM}$, as recently reported. A strong correlation was observed between $\operatorname{HP} \tau, A \beta, \alpha S$, and pTDP43 that is in line with the cross-seeding hypothesis, whereas lack of correlation between $\mathrm{HP} \tau, \mathrm{A} \beta, \alpha \mathrm{S}$, and IAPP argues against this molecular mechanism in development of these lesions. Therefore, we are unable to confirm the suggested link between AD and DM. Interestingly an association was observed between pTDP43 and IAPP/IR, not previously reported. The association IAPP/pTDP43 was strong and significant particularly in subjects with DM and high extent of IAPP/IR in pancreas. A link between IAPP/HS, TDP43/HS, and TDP43/glucose homeostasis have been recently suggested indicating that an association between these two protein alterations might be of significance [30-34]. TDP43 is ubiquitously expressed in all organs and whether phosphorylation of TDP43 is influenced by impaired glucose metabolism or pTDP43 is observed in peripheral organs in diabetes has not yet been studied. The reported association between $\mathrm{AD}$ and $\mathrm{DM}$ (epidemiological and clinical studies) might, based on our results, be related to the high incidence of pTDP43 seen postmortem in AD patients. Thus, pTDP43 should urgently be looked for in other organs in diabetics and in experimental models and the influence of glucose metabolism on phosphorylation of TDP43 should urgently be explored.

\section{ACKNOWLEDGMENTS}

We acknowledge the work of the biomedical scientist Maud Salomonsson and laboratory technician Karin Staxäng for their skillful technical assistance and Meena Strömqvist for her critical reading of the manuscript. Source of financial support include local grants (ALF) from Uppsala University Hospital and grants from Hans Gabriel and Alice Trolle-Wachtmeister foundation in Sweden. Authors' disclosures available online (http://jalz.com/manuscript-disclosures/17-0192r2).

\section{REFERENCES}

[1] Elobeid A, Libard S, Leino M, Popova SN, Alafuzoff I (2016) Altered proteins in the aging brain. J Neuropathol Exp Neurol 75, 316-325.

[2] Braak H, Alafuzoff I, Arzberger T, Kretzschmar H, Del Tredici K (2006) Staging of Alzheimer diseaseassociated neurofibrillary pathology using paraffin sections and immunocytochemistry. Acta Neuropathol 112, 389-404.

[3] Braak H, Del Tredici K, Rub U, de Vos RA, Jansen Steur EN, Braak E (2003) Staging of brain pathology related to sporadic Parkinson's disease. Neurobiol Aging 24, 197-211.

[4] McKeith IG, Dickson DW, Lowe J, Emre M, O'Brien JT, Feldman H, Cummings J, Duda JE, Lippa C, Perry EK, Aarsland D, Arai H, Ballard CG, Boeve B, Burn DJ, Costa D, Del Ser T, Dubois B, Galasko D, Gauthier S, Goetz CG, Gomez-Tortosa E, Halliday G, Hansen LA, Hardy J, Iwatsubo T, Kalaria RN, Kaufer D, Kenny RA, Korczyn A, Kosaka K, Lee VM, Lees A, Litvan I, Londos E, Lopez OL, Minoshima S, Mizuno Y, Molina JA, Mukaetova-Ladinska EB, Pasquier F, Perry RH, Schulz JB, Trojanowski JQ, Yamada M, Consortium on DLB (2005) Diagnosis and management of dementia with Lewy bodies: Third report of the DLB Consortium. Neurology 65, 1863-1872.

[5] Neumann M, Sampathu DM, Kwong LK, Truax AC, Micsenyi MC, Chou TT, Bruce J, Schuck T, Grossman M, Clark CM, McCluskey LF, Miller BL, Masliah E, Mackenzie IR, Feldman H, Feiden W, Kretzschmar HA, Trojanowski JQ, Lee VM (2006) Ubiquitinated TDP-43 in frontotemporal lobar degeneration and amyotrophic lateral sclerosis. Science 314, 130-133.

[6] Alafuzoff I, Ince PG, Arzberger T, Al-Sarraj S, Bell J, Bodi I, Bogdanovic N, Bugiani O, Ferrer I, Gelpi E, Gentleman S, Giaccone G, Ironside JW, Kavantzas N, King A, Korkolopoulou P, Kovacs GG, Meyronet D, Monoranu 
C, Parchi P, Parkkinen L, Patsouris E, Roggendorf W, Rozemuller A, Stadelmann-Nessler C, Streichenberger N, Thal DR, Kretzschmar H (2009) Staging/typing of Lewy body related alpha-synuclein pathology: A study of the BrainNet Europe Consortium. Acta Neuropathol 117, 635652.

[7] Thal DR, Rub U, Orantes M, Braak H (2002) Phases of A beta-deposition in the human brain and its relevance for the development of AD. Neurology 58, 1791-1800.

[8] Josephs KA, Murray ME, Whitwell JL, Tosakulwong N, Weigand SD, Petrucelli L, Liesinger AM, Petersen RC, Parisi JE, Dickson DW (2016) Updated TDP-43 in Alzheimer's disease staging scheme. Acta Neuropathol 131, 571-585.

[9] Kovacs GG, Alafuzoff I, Al-Sarraj S, Arzberger T, Bogdanovic N, Capellari S, Ferrer I, Gelpi E, Kovari V, Kretzschmar H, Nagy Z, Parchi P, Seilhean D, Soininen H, Troakes C, Budka H (2008) Mixed brain pathologies in dementia: The BrainNet Europe consortium experience. Dement Geriatr Cogn Disord 26, 343-350.

[10] Akter R, Cao P, Noor H, Ridgway Z, Tu LH, Wang H, Wong AG, Zhang X, Abedini A, Schmidt AM, Raleigh DP (2016) Islet amyloid polypeptide: Structure, function, and pathophysiology. J Diabetes Res 2016, 2798269.

[11] Fernandez MS (2014) Human IAPP amyloidogenic properties and pancreatic beta-cell death. Cell Calcium 56, 416-427.

[12] Yang L, Shao J, Bian Y, Wu H, Shi L, Zeng L, Li W, Dong J (2016) Prevalence of type 2 diabetes mellitus among inland residents in China (2000-2014): A meta-analysis. J Diabetes Investig 7, 845-852.

[13] Esparza TJ, Wildburger NC, Jiang H, Gangolli M, Cairns NJ, Bateman RJ, Brody DL (2016) Soluble amyloid-beta aggregates from human Alzheimer's disease brains. Sci Rep 6, 38187 .

[14] Tomita T (2012) Islet amyloid polypeptide in pancreatic islets from type 2 diabetic subjects. Islets 4, 223-232.

[15] Hazar N, Seddigh L, Rampisheh Z, Nojomi M (2016) Population attributable fraction of modifiable risk factors for Alzheimer disease: A systematic review of systematic reviews. Iran J Neurol 15, 164-172.

[16] Saedi E, Gheini MR, Faiz F, Arami MA (2016) Diabetes mellitus and cognitive impairments. World J Diabetes 7 , 412-422.

[17] Schilling MA (2016) Unraveling Alzheimer's: Making sense of the relationship between diabetes and Alzheimer's disease. J Alzheimers Dis 51, 961-977.

[18] Ono K, Takahashi R, Ikeda T, Mizuguchi M, Hamaguchi T, Yamada M (2014) Exogenous amyloidogenic proteins function as seeds in amyloid beta-protein aggregation. Biochim Biophys Acta 1842, 646-653.

[19] Moreno-Gonzalez I, Edwards Iii G, Salvadores N, Shahnawaz M, Diaz-Espinoza R, Soto C (2017) Molecular interaction between type 2 diabetes and Alzheimer's disease through cross-seeding of protein misfolding. Mol Psychiatry. doi: $10.1038 / \mathrm{mp} .2016 .230$

[20] Alafuzoff I, Aho L, Helisalmi S, Mannermaa A, Soininen H (2009) Beta-amyloid deposition in brains of subjects with diabetes. Neuropathol Appl Neurobiol 35, 60-68.

[21] Schnaider Beeri M, Silverman JM, Davis KL, Marin D, Grossman HZ, Schmeidler J, Purohit DP, Perl DP, Davidson M, Mohs RC, Haroutunian V (2005) Type 2 diabetes is negatively associated with Alzheimer's disease neuropathology. J Gerontol A Biol Sci Med Sci 60, 471-475.
[22] Moran C, Beare R, Phan TG, Bruce DG, Callisaya ML, Srikanth V (2015) Type 2 diabetes mellitus and biomarkers of neurodegeneration. Neurology 85, 1123-1130.

[23] Alafuzoff I, Thal DR, Arzberger T, Bogdanovic N, AlSarraj S, Bodi I, Boluda S, Bugiani O, Duyckaerts C, Gelpi E, Gentleman S, Giaccone G, Graeber M, Hortobagyi T, Hoftberger R, Ince P, Ironside JW, Kavantzas N, King A, Korkolopoulou P, Kovacs GG, Meyronet D, Monoranu C, Nilsson T, Parchi P, Patsouris E, Pikkarainen M, Revesz T, Rozemuller A, Seilhean D, Schulz-Schaeffer W, Streichenberger N, Wharton SB, Kretzschmar H (2009) Assessment of beta-amyloid deposits in human brain: A study of the BrainNet Europe Consortium. Acta Neuropathol 117, 309320.

[24] Thal DR, Ghebremedhin E, Rub U, Yamaguchi H, Del Tredici K, Braak H (2002) Two types of sporadic cerebral amyloid angiopathy. J Neuropathol Exp Neurol 61, 282-293.

[25] The DECODE Groupe (2003) Age- and sex-specific prevalences of diabetes and impaired glucose regulation in 13 European cohorts. Diabetes Care 26, 61-69.

[26] Clark A, Saad MF, Nezzer T, Uren C, Knowler WC, Bennett PH, Turner RC (1990) Islet amyloid polypeptide in diabetic and non-diabetic Pima Indians. Diabetologia 33, 285-289.

[27] Dall TM, Yang W, Halder P, Franz J, Byrne E, Semilla AP, Chakrabarti R, Stuart B (2016) Type 2 diabetes detection and management among insured adults. Popul Health Metr 14, 43.

[28] Eades CE, France EF, Evans JM (2016) Prevalence of impaired glucose regulation in Europe: A meta-analysis. Eur J Public Health 26, 699-706.

[29] Abner EL, Nelson PT, Kryscio RJ, Schmitt FA, Fardo DW, Woltjer RL, Cairns NJ, Yu L, Dodge HH, Xiong C, Masaki K, Tyas SL, Bennett DA, Schneider JA, Arvanitakis Z (2016) Diabetes is associated with cerebrovascular but not Alzheimer neuropathology. Alzheimers Dement 12, 882-889.

[30] Roostaei T, Nazeri A, Felsky D, De Jager PL, Schneider JA, Pollock BG, Bennett DA, Voineskos AN (2017) Genomewide interaction study of brain beta-amyloid burden and cognitive impairment in Alzheimer's disease. Mol Psychiatry 22, 287-295.

[31] Nelson PT, Katsumata Y, Nho K, Artiushin SC, Jicha GA, Wang WX, Abner EL, Saykin AJ, Kukull WA, Fardo DW (2016) Genomics and CSF analyses implicate thyroid hormone in hippocampal sclerosis of aging. Acta Neuropathol 132, 841-858.

[32] Wilson AC, Dugger BN, Dickson DW, Wang DS (2011) TDP-43 in aging and Alzheimer's disease - a review. Int J Clin Exp Pathol 4, 147-155.

[33] Amador-Ortiz C, Ahmed Z, Zehr C, Dickson DW (2007) Hippocampal sclerosis dementia differs from hippocampal sclerosis in frontal lobe degeneration. Acta Neuropathol 3, 245-252.

[34] Stallings NR, Puttaparthi K, Dowling KJ, Luther CM, Burns DK, Davis K, Elliott JL (2013) TDP-43, an ALS linked protein, regulates fat deposition and glucose homeostasis. PLoS One 8, e71793.

[35] Buratti E, Baralle FE (2010) The multiple roles of TDP-43 in pre-mRNA processing and gene expression regulation. RNA Biol 7, 420-429.

[36] Sephton CF, Cenik C, Kucukural A, Dammer EB, Cenik B, Han Y, Dewey CM, Roth FP, Herz J, Peng J, Moore MJ, Yu G (2011) Identification of neuronal RNA targets of TDP-43- 
containing ribonucleoprotein complexes. J Biol Chem 286, 1204-1215.

[37] Josephs KA, Murray ME, Whitwell JL, Parisi JE, Petrucelli L, Jack CR, Petersen RC, Dickson DW (2014) Staging TDP43 pathology in Alzheimer's disease. Acta Neuropathol 127, 441-450.

[38] Miklossy J, Qing H, Radenovic A, Kis A, Vileno B, Laszlo F, Miller L, Martins RN, Waeber G, Mooser V, Bosman F, Khalili K, Darbinian N, McGeer PL (2010) Beta amyloid and hyperphosphorylated tau deposits in the pancreas in type 2 diabetes. Neurobiol Aging 31, 1503-1515.

[39] Jackson K, Barisone GA, Diaz E, Jin LW, DeCarli C, Despa F (2013) Amylin deposition in the brain: A second amyloid in Alzheimer disease? Ann Neurol 74, 517-526.

[40] Ridler C (2017) Alzheimer disease: Misfolded diabetesmellitus peptide seeds amyloid-beta aggregation. Nat Rev Neurol 13, 128.

[41] Hayashi T, Ago K, Nakamae T, Higo E, Ogata M (2015) Two different immunostaining patterns of beta-amyloid precursor protein (APP) may distinguish traumatic from nontraumatic axonal injury. Int J Legal Med 129, 10851090.

[42] Langa KM, Larson EB, Crimmins EM, Faul JD, Levine DA, Kabeto MU, Weir DR (2017) A comparison of the prevalence of dementia in the United States in 2000 and 2012. JAMA Intern Med 177, 51-58.

[43] McAleese KE, Alafuzoff I, Charidimou A, De Reuck J, Grinberg LT, Hainsworth AH, Hortobagyi T, Ince P, Jellinger K, Gao J, Kalaria RN, Kovacs GG, Kovari E, Love S, Popovic M, Skrobot O, Taipa R, Thal DR, Werring D, Wharton SB, Attems J (2016) Post-mortem assessment in vascular dementia: Advances and aspirations. BMC Med 14, 129.

[44] Akomolafe A, Beiser A, Meigs JB, Au R, Green RC, Farrer LA, Wolf PA, Seshadri S (2006) Diabetes mellitus and risk of developing Alzheimer disease: Results from the Framingham Study. Arch Neurol 63, 1551-1555.

[45] Peila R, Rodriguez BL, Launer LJ, Honolulu-Asia Aging S (2002) Type 2 diabetes, APOE gene, and the risk for dementia and related pathologies: The Honolulu-Asia Aging Study. Diabetes 51, 1256-1262.

[46] Arvanitakis Z, Schneider JA, Wilson RS, Li Y, Arnold SE, Wang Z, Bennett DA (2006) Diabetes is related to cere- bral infarction but not to AD pathology in older persons. Neurology 67, 1960-1965.

[47] Heitner J, Dickson D (1997) Diabetics do not have increased Alzheimer-type pathology compared with age-matched control subjects. A retrospective postmortem immunocytochemical and histofluorescent study. Neurology 49, 1306-1311.

[48] Petrovitch H, White LR, Izmirilian G, Ross GW, Havlik RJ, Markesbery W, Nelson J, Davis DG, Hardman J, Foley DJ, Launer LJ (2000) Midlife blood pressure and neuritic plaques, neurofibrillary tangles, and brain weight at death: The HAAS. Honolulu-Asia aging Study. Neurobiol Aging 21, 57-62.

[49] Ahtiluoto S, Polvikoski T, Peltonen M, Solomon A, Tuomilehto J, Winblad B, Sulkava R, Kivipelto M (2010) Diabetes, Alzheimer disease, and vascular dementia: A population-based neuropathologic study. Neurology $\mathbf{7 5}$, 1195-1202.

[50] Sonnen JA, Larson EB, Brickell K, Crane PK, Woltjer R, Montine TJ, Craft S (2009) Different patterns of cerebral injury in dementia with or without diabetes. Arch Neurol 66, 315-322.

[51] Kuo SC, Lai SW, Hung HC, Muo CH, Hung SC, Liu LL, Chang CW, Hwu YJ, Chen SL, Sung FC (2015) Association between comorbidities and dementia in diabetes mellitus patients: Population-based retrospective cohort study. J Diabetes Complications 29, 1071-1076.

[52] Hyman BT, Phelps CH, Beach TG, Bigio EH, Cairns NJ, Carrillo MC, Dickson DW, Duyckaerts C, Frosch MP, Masliah E, Mirra SS, Nelson PT, Schneider JA, Thal DR, Thies B, Trojanowski JQ, Vinters HV, Montine TJ (2012) National Institute on Aging-Alzheimer's Association guidelines for the neuropathologic assessment of Alzheimer's disease. Alzheimers Dement 8, 1-13.

[53] Montine TJ, Phelps CH, Beach TG, Bigio EH, Cairns NJ, Dickson DW, Duyckaerts C, Frosch MP, Masliah E, Mirra SS, Nelson PT, Schneider JA, Thal DR, Trojanowski JQ, Vinters HV, Hyman BT, National Institute on Aging, Alzheimer's, Association (2012) National Institute on Aging-Alzheimer's Association guidelines for the neuropathologic assessment of Alzheimer's disease: A practical approach. Acta Neuropathol 123, 1-11. 